\title{
The Potential for the Treatment of Antimony-Containing Wastewater by Iron-Based Adsorbents
}

\author{
Ren-Jian Deng ${ }^{1,2}$, Chang-Sheng Jin ${ }^{1}$, Bo-Zhi Ren ${ }^{1,2}$, Bao-Lin Hou ${ }^{1,2}$ and \\ Andrew S. Hursthouse 1,2,3,* \\ 1 School of Civil Engineering, Hunan University of Science and Technology, Xiangtan 411201, China; \\ 800912deng@sina.com (R.-J.D.); jinchangshengcn@163.com (C.-S.J.); xtrbzt@sina.com (B.-Z.R.); \\ hbl527@163.com (B.-L.H.) \\ 2 Hunan Provincial Key Laboratory of Shale Gas Resource Utilization, Xiangtan 411201, China \\ 3 School of Science \& Sport, University of the West of Scotland, Paisley PA1 2BE, UK \\ * Correspondence: andrew.hursthouse@uws.ac.uk
}

Received: 1 September 2017; Accepted: 12 October 2017; Published: 16 October 2017

\begin{abstract}
Antimony (Sb) and its compounds are considered as global priority pollutants. Elevated concentrations of antimony in natural and industrial process wastewater are of global concern, particularly given interest in the potential toxicity and harm to the environment from aquatic exposure. Iron-based materials for treatment by adsorption are widely regarded to have potential merit for the removal of trace contaminants from water and especially in the search for efficient and low-cost techniques. In this paper, we review the application of iron-based materials in the sorption treatment of antimony contaminated water. The interaction of $\mathrm{Sb}$ is discussed in relation to adsorption performance, influencing factors, mechanism, modelling of adsorption (isotherm, kinetic and thermodynamic models), advantages, drawbacks and the recent achievements in the field. Although iron-based adsorbents show promise, the following three aspects are in need of further study. Firstly, a select number of iron based binary metal oxide adsorbents should be further explored as they show superior performance compared to other systems. Secondly, the possibility of redox reactions and conversion between $\mathrm{Sb}(\mathrm{III})$ and $\mathrm{Sb}(\mathrm{V})$ during the adsorption process is unclear and requires further investigation. Thirdly, in order to achieve optimized control of preferential adsorption sites and functional groups, the mechanism of antimony removal has to be qualitatively and quantitatively resolved by combining the advantages of advanced characterization techniques such as Fourier transform infrared spectroscopy(FTIR), X-ray photoelectron spectroscopy (XPS), Atomic force microscope(AFM), X-ray absorption near edge structure(XANES), and other spectroscopic methods. We provide details on the achievements and limitations of each of these stages and point to the need for further research.
\end{abstract}

Keywords: antimony; Sb-containing wastewater; iron-based adsorbent; wastewater treatment; adsorption

\section{Introduction}

Antimony ( $\mathrm{Sb}$ ) is a naturally occurring chalcophilic element, which predominantly exists as $\mathrm{Sb}$ (III) and $\mathrm{Sb}(\mathrm{V})$ in the aquatic environment [1]. It has increasingly become regarded as a potentially toxic element and human carcinogen with the toxicity of $\mathrm{Sb}(\mathrm{III})$ being ten times higher than $\mathrm{Sb}(\mathrm{V})$ [2]. Human exposure to antimony is primarily through contaminated water and food, causing damage to the liver, lungs and cardiovascular system [3], and $\mathrm{Sb}$ can have wide geographical impacts because of its mobility and complexation reactions in water and with sediments [4]. Thus, antimony and its compounds are considered as priority pollutants by many national and international regulators [5], such as European 
Commission and Environmental Protection Agency of the United States. Due to a variety of industrial activities, about $3.8 \times 10^{4}$ tons of $\mathrm{Sb}$-containing compounds are released annually into the global environment. China is the largest $\mathrm{Sb}$ producer in the world with $114 \mathrm{Sb}$ mines and approximately $90 \%$ of the world's production [1,6]. However, due to the complex characteristics of Sb-containing wastewater [7], poor uptake of treatment technology, and long term management issues from historic production, many surface and groundwater bodies are seriously polluted, and receive direct discharges without appropriate recovery or treatment methods. This is particularly acute in the Hunan, Guizhou and Guangxi provinces of China [8,9]. The world largest antimony mine, Xikuangshan in Hunan province features $\mathrm{Sb}$ concentrations in surface water around the mining and smelter areas of up to 1300 to 5000 times the Chinese drinking water limit $(5 \mu \mathrm{g} / \mathrm{L})$ [8]. Antimony poisoning and pollution events occur with increasing frequency, which pose an adverse impact on the local ecosystem, food safety, drinking water security and on human health $[10,11]$. This means that effective treatment methods for $\mathrm{Sb}$-containing wastewater discharges are essential for environmental improvement and to protect human health.

Recently, scientific research has focused on the remediation of Sb-contaminated soil $[9,12]$, the conversion between $\mathrm{Sb}(\mathrm{III})$ and $\mathrm{Sb}(\mathrm{V})$ oxidation states and influence on their chemical behaviour [13-15], and the toxicology and environmental risk assessment process with specific reference to $\mathrm{Sb}[16,17]$. Consequently, studies have also looked at novel techniques to control antimony pollution [18]. These have included a variety of methods, such as traditional coagulation and precipitation [19-21], biological systems [22-25], ion-exchange [26-28], membrane separation [29-31], adsorption [32-34], oxidation and electrochemical methods [35]. Among them, adsorption, widely used for the removal of trace contaminants from waters, has been proven to be an effective technology to remove antimony from the aqueous systems. Approaches have used a wide range of adsorption materials, amongst which iron-based adsorbents have performed well in the sequestration of $\mathrm{Sb}$ ions from aqueous solutions. The advantages appear to arise from their considerable adsorption capacities, abundance and they are relatively easy to acquire.

We present a review of the main factors influencing the sorption process and relative performance of a range of materials. This includes $\mathrm{pH}$, contact time, initial concentration, adsorbent dose, temperature, specific surface area and co-existing/competing ions of $\mathrm{Sb}$ adsorption onto iron adsorbents. The adsorption isotherms and kinetics, thermodynamic models and adsorption mechanism are discussed in detail, in order to provide theoretical and technical support for efficient adsorption treatment of Sb-containing wastewater. We ultimately aim to find a cost-effective adsorbent for $\mathrm{Sb}$-containing wastewater treatment, especially focused on the large-scale challenges in China.

\section{Characteristics of Adsorption Treatment of Sb-Containing Wastewater by Iron Adsorbents}

\subsection{The Range of Iron-Based Adsorbents for Antimony and Their Adsorption Capacity}

This section presents an overview of recent studies published on antimony removal from aqueous system by various ferric iron adsorbents, including iron oxides, binary metal iron oxides, Fe-loaded composite adsorbents, zero-valent iron and ferric iron enriched soil. Table 1 summarizes the $\mathrm{Sb}$ adsorption characteristics for different types of iron-based adsorbents. 
Table 1. Maximum adsorption capacities $\left(Q_{m}\right)$ reported in literature for antimony removal from aqueous solutions.

\begin{tabular}{|c|c|c|c|c|c|c|c|c|c|}
\hline Adsorbent & Initial Concentration Range $(\mathrm{mg} / \mathrm{L})$ & Sb Oxidation State & $\mathrm{pH}$ & $\mathrm{T}(\mathrm{K})$ & Adsorbent Dose (g/L) & Contact Time (h) & $\mathrm{Q}_{\mathrm{m}}(\mathrm{mg} / \mathrm{g})$ & Removal Rate (\%) & Reference \\
\hline \multicolumn{10}{|l|}{ Iron oxides } \\
\hline Ferric hydroxide & $24-244$ & $\mathrm{Sb}(\mathrm{III})$ & 3 & 293 & 0.2 & 24 & 101 & - & [36] \\
\hline Ferric hydroxide & 60.88 & $\mathrm{Sb}(\mathrm{V})$ & 5 & 293 & 0.2 & 24 & 99.84 & - & [37] \\
\hline Ferric hydroxide & $0-25$ & $\mathrm{Sb}(\mathrm{V})$ & 4 & 298 & 0.2 & 24 & 18.5 & - & [38] \\
\hline $\mathrm{Fe}(\mathrm{OH})_{3}$ & $0.02-1.8$ & $\mathrm{Sb}(\mathrm{V})$ & $6-7$ & - & 0.5 & 24 & - & $>90$ & [39] \\
\hline Goethite & $0.05-15$ & $\mathrm{Sb}(\mathrm{V})$ & 7 & 298 & 1 & 24 & 18.3 & 99 & [40] \\
\hline Goethite & $4.79-47.93$ & $\mathrm{Sb}(\mathrm{III})$ & 3.9 & 298 & 0.697 & 24 & 69.8 & - & [41] \\
\hline Ferrihydrite & $0.121-24.35$ & $\mathrm{Sb}(\mathrm{V})$ & 5 & 298 & 0.5 & 12 & 27.9 & 93.3 & [42] \\
\hline Akaganeite & $1-1000$ & $\mathrm{Sb}(\mathrm{V})$ & 2.2 & - & 2 & - & 450.4 & - & [43] \\
\hline Alpha- $-\mathrm{Fe}_{2} \mathrm{O}_{3}$ & 19.48 & $\mathrm{Sb}(\mathrm{V})$ & 4 & 303 & 0.75 & - & 7 & - & [44] \\
\hline Hydrous ferric oxide & 12.2 & $\mathrm{Sb}(\mathrm{V})$ & 4 & 293 & 0.4 & 24 & 114 & - & [45] \\
\hline$\gamma$-FeOOH & 6.09 & $\mathrm{Sb}(\mathrm{V})$ & 4 & 293 & 0.4 & 24 & 34.09 & - & [45] \\
\hline \multirow{2}{*}{$\beta$-FeOOH } & 6.09 & $\mathrm{Sb}(\mathrm{V})$ & 4 & 293 & 0.4 & 24 & 29.22 & - & [45] \\
\hline & 6.09 & $\mathrm{Sb}$ (III) & 9 & 293 & 0.4 & 24 & 34.09 & - & [45] \\
\hline \multirow{2}{*}{$\alpha-\mathrm{FeOOH}$} & 6.09 & $\mathrm{Sb}(\mathrm{V})$ & 4 & 293 & 0.4 & 24 & 24.47 & - & [45] \\
\hline & 6.09 & $\mathrm{Sb}(\mathrm{III})$ & 9 & 293 & 0.4 & 24 & 53.45 & - & [45] \\
\hline \multicolumn{10}{|l|}{ Binary metal Iron oxides } \\
\hline Iron-zirconium bimetal oxide & $0-25$ & $\mathrm{Sb}(\mathrm{V})$ & 7 & 298 & 0.2 & 3 & 60.4 & - & [38] \\
\hline Iron-zirconium bimetal oxide & 20 & $\mathrm{Sb}(\mathrm{V})$ & $2-5$ & 298 & 0.5 & 2 & 35.7 & - & [46] \\
\hline Fe-Mn binary oxide & 60.88 & $\mathrm{Sb}(\mathrm{V})$ & 5 & - & 0.2 & 24 & 127.84 & - & [37] \\
\hline Fe-Mn binary oxide & $24.35-243.5$ & $\mathrm{Sb}(\mathrm{III})$ & 3 & 293 & 0.2 & 5 & 214.28 & - & [36] \\
\hline \multirow{2}{*}{ Fe-Cu binary oxide } & 40 & $\mathrm{Sb}(\mathrm{III})$ & $2-10$ & 298 & 0.04 & 24 & 111.27 & 88.31 & [47] \\
\hline & 40 & $\mathrm{Sb}(\mathrm{V})$ & 5 & 298 & 0.04 & 24 & 104.95 & 85.46 & [47] \\
\hline \multicolumn{10}{|l|}{ Fe-loaded composite adsorbents } \\
\hline Hematite modified magnetic nanoparticles & 0.11 & $\mathrm{Sb}(\mathrm{III})$ & 4.1 & 298 & 0.1 & 2 & 36.7 & $>95.5$ & [48] \\
\hline Fe-Zr-D201 & $0-120$ & $\mathrm{Sb}(\mathrm{V})$ & $2.8-4.3$ & 298 & 0.25 & 8.33 & 73.75 & 98.9 & [49] \\
\hline Iron-oxide coated sand & 33.3 & Total Sb & 6 & 313 & 1.5 & 7 & 0.6 & $>95$ & [50] \\
\hline \multirow[t]{2}{*}{$\mathrm{Fe}$ (II)-loaded saponified orange waste } & 5.5 & $\mathrm{Sb}(\mathrm{III})$ & 2.7 & 303 & $\begin{array}{l}5 \\
5\end{array}$ & 24 & $\begin{array}{l}136.36 \\
174.88\end{array}$ & 100 & [51] \\
\hline & 3.5 & $\mathrm{Sb}(\mathrm{V})$ & 2.7 & 303 & 5 & 24 & 144.88 & 96 & [51] \\
\hline \multirow{2}{*}{$\mathrm{Zr}(\mathrm{IV})$ and $\mathrm{Fe}(\mathrm{III})$ loaded orange waste } & 15 & $\mathrm{Sb}$ (III) & 2.5 & 303 & 1.67 & 24 & 170.45 & 100 & [51] \\
\hline & 15 & $\mathrm{Sb}(\mathrm{V})$ & 2.5 & 303 & 1.67 & 24 & 227.67 & 100 & [51] \\
\hline
\end{tabular}


Table 1. Cont

\begin{tabular}{|c|c|c|c|c|c|c|c|c|c|}
\hline Adsorbent & Initial Concentration Range $(\mathrm{mg} / \mathrm{L})$ & Sb Oxidation State & $\mathrm{pH}$ & $\mathrm{T}(\mathrm{K})$ & Adsorbent Dose (g/L) & Contact Time (h) & $Q_{m}(\mathrm{mg} / \mathrm{g})$ & Removal Rate (\%) & Reference \\
\hline $\mathrm{FeCl}_{3}$-modifed sepiolite & 50 & $\mathrm{Sb}(\mathrm{III})$ & 6.8 & 308 & 2 & 1.5 & 21.63 & - & [32] \\
\hline $\mathrm{FeCl}_{3}$-modifed activated carbon & 1.5 & $\mathrm{Sb}$ (III) & $5-9$ & 298 & 1 & & - & $>96$ & [52] \\
\hline Iron-oxide coated olivine & - & $\mathrm{Sb}(\mathrm{V})$ & $4-5$ & 298 & 2.5 & - & - & 99 & [53] \\
\hline $\mathrm{Fe}_{2} \mathrm{O}_{3}$ modified carbon nanotubes (CNTs) & 1.5 & $\mathrm{Sb}$ (III) & 7 & 298 & 0.5 & 2 & 6.3 & 99.97 & [33] \\
\hline Graphene oxide and it's magnetite composites & $0-150$ & $\mathrm{Sb}$ (III) & 3-9 & 298 & 1.2 & 2 & 8.7 & $>95$ & [54] \\
\hline $\begin{array}{l}\text { Polymeric anion exchanger D201 loaded with } \\
\text { nano hydrated ferric oxide (HFO) }\end{array}$ & $5-80$ & $\mathrm{Sb}(\mathrm{V})$ & 3 & 303 & 0.2 & 5 & 60.9 & 99 & [55] \\
\hline Calcite sands loaded with nano HFO & $5-80$ & $\mathrm{Sb}(\mathrm{V})$ & 4 & 303 & 0.2 & 5 & 39.9 & 99 & [55] \\
\hline $\begin{array}{l}\text { Iron-modified attapulgite } \mathrm{Nano}-\mathrm{FeO}(\mathrm{OH}) \\
\text { modified clinoptilolite tuff }\end{array}$ & $\begin{array}{l}5-80 \\
-\end{array}$ & $\begin{array}{l}\mathrm{Sb}(\mathrm{V}) \\
\mathrm{Sb}(\mathrm{III})\end{array}$ & $\begin{array}{c}6.8 \\
<2.7\end{array}$ & $\begin{array}{c}- \\
296\end{array}$ & 0.1 & $\begin{array}{c}15 \\
-\end{array}$ & $\begin{array}{c}31.79 \\
7.17\end{array}$ & $\begin{array}{c}78 \\
-\end{array}$ & $\begin{array}{l}{[34]} \\
{[56]}\end{array}$ \\
\hline $\mathrm{Fe}(\mathrm{III})$-treated bacteria aerobic granules & 20 & $\mathrm{Sb}(\mathrm{V})$ & 3.4 & 308 & 20 & 5 & 22.6 & $>95$ & [23] \\
\hline $\mathrm{Fe}(\mathrm{III})$-treated fungi aerobic granules & 20 & $\mathrm{Sb}(\mathrm{V})$ & 3.4 & 318 & 20 & 5 & 19 & $>95$ & [57] \\
\hline Zeolite-supported magnet-ite & 5.1 & $\mathrm{Sb}(\mathrm{V})$ & $2-4$ & 298 & 0.5 & 13 & 19 & 85 & [58] \\
\hline $\mathrm{Fe}_{2} \mathrm{O}_{3}-\mathrm{Fe}_{3} \mathrm{O}_{4} / \mathrm{C}$ prepared with bamboo template & 5-150 & $\mathrm{Sb}$ (III) & 7 & 298 & 2 & - & 4.782 & $>90$ & [59] \\
\hline $\begin{array}{l}\mathrm{Fe}_{2} \mathrm{O}_{3}-\mathrm{Fe}_{3} \mathrm{O}_{4} / \mathrm{C} \text { prepared with eucalyptus } \\
\text { wood template }\end{array}$ & 50 & $\mathrm{Sb}(\mathrm{III})$ & 8 & 298 & 10 & - & 4.45 & $>90$ & [60] \\
\hline \multicolumn{10}{|l|}{ Zero-valent iron } \\
\hline Nanoscale zero-valent iron & $\begin{array}{l}0-20 \\
0-20\end{array}$ & $\begin{array}{l}\mathrm{Sb}(\mathrm{III}) \\
\mathrm{Sb}(\mathrm{V})\end{array}$ & $\begin{array}{l}<5.0 \\
<5.0\end{array}$ & $\begin{array}{l}298 \\
298\end{array}$ & $\begin{array}{l}2 \\
2\end{array}$ & $\begin{array}{l}48 \\
48\end{array}$ & $\begin{array}{l}6.99 \\
1.65\end{array}$ & - & $\begin{array}{l}{[61]} \\
{[61]}\end{array}$ \\
\hline Zero-valent iron (under the weak magnetic field) & $1-5$ & $\mathrm{Sb}(\mathrm{IIII})$ & 5.0 & 298 & 0.1 & - & - & $>90$ & [62] \\
\hline Zero-valent iron & 5.0 & $\mathrm{Sb}$ (III) & 5.0 & 298 & 3 & - & - & 69.98 & [63] \\
\hline \multicolumn{10}{|l|}{ Ferric-Iron rich soil } \\
\hline Red soil & $2.44-180.19$ & $\mathrm{Sb}(\mathrm{V})$ & 4.8 & 298 & 60 & $>720$ & 1.68 & - & [64] \\
\hline
\end{tabular}


As Table 1 shows, the maximum adsorption capacities $\left(Q_{m}\right)$ reported in literature for different kinds of iron based adsorbents vary by four orders of magnitude with a range between $0.6 \mathrm{mg} / \mathrm{g}$ and $450.4 \mathrm{mg} / \mathrm{g}$. The $\mathrm{Q}_{\mathrm{m}}$ values were mostly obtained by the analysis of the adsorption isotherm from experimental data. Among these adsorbents, $\mathrm{Q}_{\mathrm{m}}$ value of akaganeite (a Ferric iron oxide/hydroxide (+ minor chloride/nickel)) reached $450.4 \mathrm{mg} / \mathrm{g}$, which is significantly higher than the $\mathrm{Q}_{\mathrm{m}}$ values of many other iron-based adsorption materials. The main reason for the high capacity is that akaganeite has a large surface area and very porous structure. It is also worth noting that binary metal oxides such as Fe-Mn oxide $[36,37,47,51]$ are also promising adsorbents with relatively high $Q_{m}$ values [35]. The value for $\mathrm{Q}_{\mathrm{m}}$ is also dependent on a number of experimental factors such as $\mathrm{pH}$, contact time, initial concentrations, adsorbent dose, temperature, specific surface area and co-existing/competing ions. It is important to emphasize that many published studies presenting $\mathrm{Q}_{\mathrm{m}}$ values do not seem to take these key factors into consideration, which makes direct comparison of performance very difficult. This must be a focus for further studies on the treatment of Sb-containing wastewater.

\subsection{Effect of $p H$}

$\mathrm{Sb}$ speciation in aqueous solutions is dominated by $\mathrm{pH}$ and redox potential (Eh), and within the $\mathrm{pH}$ range 5.0 to 10.0 , the two dominant inorganic forms of $\mathrm{Sb}$ in contaminated wastewater are the antimonite anion $(\mathrm{V}), \mathrm{Sb}(\mathrm{OH})_{6}{ }^{-}$, and antimony III hydroxide, $\mathrm{Sb}(\mathrm{OH})_{3}$, (stable over $\mathrm{pH}$ range 2.0 to $10.0[35,63])$. Other hydroxyl species are also present, with varying ionic charge and consequently the two oxidation states of $\mathrm{Sb}$ have different chemical properties and the optimal $\mathrm{pH}$ for removal varies. A number of studies report that when $\mathrm{pH}$ is within the range 2-10, the sorption of $\mathrm{Sb}(\mathrm{V})$ by most iron based adsorbents increases significantly as the $\mathrm{pH}$ is increased from 2 to 3 , maintaining the maximum sorption plateau over the $\mathrm{pH}$ range of 3 to 5 , but decreasing significantly as the $\mathrm{pH}$ was increased above 5 . As shown in Table 1, the optimum $\mathrm{pH}$ range for $\mathrm{Sb}(\mathrm{V})$ removal was 3-4 using $\mathrm{Fe}_{3} \mathrm{O}_{4}$ [58]. Similar results were reported for the removal of $\mathrm{Sb}(\mathrm{V})$ using different iron based adsorbents, such as ferric hydroxide [37,38],hematite [48], hydrous ferric oxide [45,55], zero-valent iron [61-63], and Fe(III)-treated aerobic granules [23,57]. The change in sorption behaviour of $\mathrm{Sb}(\mathrm{V})$ can be explained in terms of range of ionic $\mathrm{Sb}(\mathrm{V})$ species, which stabilise as $\mathrm{pH}$ changes. For $\mathrm{pH}$ value between 5.0 to $10.0, \mathrm{Sb}(\mathrm{V})$ exists as $\left[\mathrm{Sb}(\mathrm{OH})_{6}{ }^{-}\right.$] species [65], the low sorption of $\mathrm{Sb}(\mathrm{V})$ is likely due to competition for adsorption sites between hydroxyl ions. Thus, the optimum $\mathrm{pH}$ value for adsorption is also related to the point of zero charge $\left(\mathrm{pH}_{\mathrm{zpc}}\right)$ of the adsorbent in the solution. When $\mathrm{pH}<\mathrm{pH}_{\mathrm{zpc}}$, the protonation reaction on the surface of ferric adsorbents results in the surface being positively charged, which ultimately leads to the increased adsorption of metal ions due to the higher concentration of $\mathrm{H}^{+}$ions in the reaction mixture, promoting the removal of $\mathrm{Sb}(\mathrm{V})$. Conversely, when $\mathrm{pH}>\mathrm{pH}_{\mathrm{zpc}}$, the adsorption surface is negatively charged and also the adsorbate species are negatively charged. Thus, the adsorption performance is affected through the process of electrostatic repulsion $[42,49,66]$. In order to obtain good removal efficiency of $\mathrm{Sb}(\mathrm{V})$, the $\mathrm{pH}$ value should be kept below the $\mathrm{pH}_{\mathrm{zpc}}$ of the iron adsorbents within the $\mathrm{pH}$ range of 2.0-5.0. For $\mathrm{Sb}(\mathrm{III})$, the neutral $\left[\mathrm{H}_{3} \mathrm{SbO}_{3}\right]$ species dominates over a wide $\mathrm{pH}$ range (2-10) [65].Thus, a change in $\mathrm{pH}$ value has little influence on the removal efficiency of $\mathrm{Sb}(\mathrm{III})$ compared to $\mathrm{Sb}(\mathrm{V})$. Therefore, $\mathrm{Sb}$ (III) removal capacities are constant over a broad $\mathrm{pH}$ range. As shown in Table 1, the optimum $\mathrm{pH}$ value was in the range 3-9, 2-10 and 5-9 for removal using graphene oxide and magnetite composites [54], with $\mathrm{Fe}-\mathrm{Cu}$ binary oxide [47] and with $\mathrm{FeCl}_{3}$-modifed activated carbon [52], respectively. When the $\mathrm{pH}$ value exceeds 10.0, both the generation of ferric hydroxide generation and solubility of iron salts has been inhibited, which decreases the adsorption efficiency. As a result, the $\mathrm{pH}$ value for the removal of $\mathrm{Sb}$ (III) should not be higher than 12.0. It is useful to note that some adsorbents such as $\beta$-FeOOH [45], iron-zirconium binary oxide [38], Fe-Cu binary oxide [47] and iron-modified attapulgite [34] exhibit high adsorption capacities and removal rate for $\mathrm{Sb}$ when solution $\mathrm{pH}$ values are around 7. These iron adsorbents have advantages over other adsorbents in this application. In conclusion, $\mathrm{pH}$ will not only affect the 
speciation of antimony ions in water, but will also determine the surface charge of adsorption materials. Thus, the $\mathrm{pH}$ value is one of the most important factors influencing the adsorption behaviour.

\subsection{Effect of Contact Time}

Table 1 indicates that the equilibration time for adsorbing of $\mathrm{Sb}$ by most iron-based adsorbents is less than $24 \mathrm{~h}$. Other recently developed adsorption materials, such as iron-zirconium bimetal oxide [46], hematite-modified magnetic nanoparticles [48] and $\mathrm{Fe}_{2} \mathrm{O}_{3}$-modified carbon nanotubes (CNTs) [33] reach adsorption equilibrium within $2 \mathrm{~h}$. These adsorbents show a more significant potential for application compared with other materials. The adsorption process, as a function of contact time, generally undergoes two phases, namely, fast and slow, similar to what has been extensively reported in literature $[24,40]$. The fast adsorption phase is likely due to the abundant availability of active sites on adsorbents. When available sorption sites are occupied, adsorption becomes less efficient and leads to a slow adsorption phase. For example, within the first $10 \mathrm{~min}$, the amount of $\mathrm{Sb}(\mathrm{III})$ adsorbed onto hematite-modified magnetic nanoparticles is nearly $95.4 \%$. A steady state is achieved after approximately $60 \mathrm{~min}$, and the amount of adsorbed $\mathrm{Sb}(\mathrm{III})$ is approximately $98.5 \%$ [48]. The removal rates of $\mathrm{Sb}(\mathrm{V})$ by iron-modified attapulgite and Fe-Mn binary oxide reach $90 \%$ within $5 \mathrm{~h}$, but the time required to reach adsorption equilibrium is 12 and $24 \mathrm{~h}$, respectively [34,37]. Many similar results were obtained in other studies when Fe-Zr-D201 [49], graphene oxide and magnetite composites [54] were applied to remove $\mathrm{Sb}(\mathrm{III})$ or $\mathrm{Sb}(\mathrm{V})$ from wastewater. Although the duration of the slow adsorption phase is several times that of the fast adsorption phase, the amounts of adsorbed $\mathrm{Sb}$ in the two phases is approximately $80 \%$ to $90 \%$ and $10 \%$ to $20 \%$ of the total initial $\mathrm{Sb}$, respectively. The fast adsorption phase plays a leading role in the adsorption process. Overall, the adsorption capacity and removal rate increase with the extension of adsorption time, but the size of the contact reactor also increases in the practical engineering deployment of this technology. This increase in reactor size raises construction costs. Therefore, contact time is an essential parameter in the actual treatment of antimony-containing wastewater.

\subsection{Effect of Initial Concentration Range and Adsorbents Dose}

Previous studies $[23,54,57,67]$ have shown that the $Q_{m}$ of iron-based adsorbents increases with the increase in initial $\mathrm{Sb}$ concentration, but the removal rate significantly declines. The reason is that increments in initial concentration can stimulate adsorbents to produce numerous effective sites, but the increased proportion of effective sites is much less than the increased solute concentration. Table 1 shows that several adsorbents, such as hematite-modified magnetic nanoparticles [48], $\mathrm{FeCl}_{3}$-modifed activated carbon [52], iron oxide-coated olivine [53], zero-valent iron [62,63], Fe(III)-loaded saponified orange waste [51] and zeolite-supported magnetite [58], can achieve significant treatment effects when the initial concentration of antimony is low $(<6 \mathrm{mg} / \mathrm{L})$. By contrast, other adsorbents, such as Fe-Zr-D201 [49], graphene oxide and its magnetite composites [54], Fe-Mn binary oxide [36,37], $\mathrm{FeCl}_{3}$-modifed sepiolite [32], and $\mathrm{Fe}_{2} \mathrm{O}_{3}-\mathrm{Fe}_{3} \mathrm{O}_{4} / \mathrm{C}$ prepared with eucalyptus wood template [60] and ferric hydroxide [37], can achieve excellent treatment effects over a wide range of initial concentrations. Ferric iron-based adsorbents can be selected according to the initial concentration of $\mathrm{Sb}$ and cost performance.

Treatment efficiency and cost are directly influenced by adsorbent dose in the adsorption process. Table 1 indicates that the optimum dosing ratio (adsorption dose $(\mathrm{mg} / \mathrm{L}): \mathrm{Sb}$ concentration $(\mathrm{mg} / \mathrm{L})$ ) of different iron adsorption materials vary within a wide range of 1 to 1000 . The optimum dosing ratio of Fe-Cu binary oxide [47] is only 1 and is one of the lowest ratios reported for all iron-based adsorbents. The adsorbent with the highest dosing ratio of 1000 has been reported for Fe(III)-treated aerobic granules [23,57]. Iron oxide adsorbents, such as ferric hydroxide [36-38], hydrous ferric oxide [45], alpha- $\mathrm{Fe}_{2} \mathrm{O}_{3}$ [44], zero-valence iron [63] and ferrihydrite [68], can achieve considerable $\mathrm{Sb}$ removal efficiency when the dosing ratio is less than 80. Meanwhile, iron-based organic adsorbents, such as Fe-Zr-D201 [49], Fe(III)-loaded saponified orange waste [51], Zr(IV)- and Fe(III)-loaded orange 
waste [51], $\mathrm{Fe}_{2} \mathrm{O}_{3}-\mathrm{Fe}_{3} \mathrm{O}_{4} / \mathrm{C}$ prepared with bamboo template [59], $\mathrm{Fe}_{2} \mathrm{O}_{3}-\mathrm{Fe}_{3} \mathrm{O}_{4} / \mathrm{C}$ prepared with eucalyptus wood template [60], $\mathrm{Fe}(\mathrm{III})$-treated bacteria/fungi aerobic granules [23,57] and red soil [64], achieve considerable $\mathrm{Sb}$ removal efficiency when the ratio is $>100$. Therefore, the adsorption capacity of ion oxides for $\mathrm{Sb}$ is higher than that of organo-iron adsorbents. Adsorbents exhibit an optimal concentration when other conditions are constant, and continuing to enhance the dose of adsorbents produces excess adsorption sites. Suitable adsorbents can only be selected under optimal experimental conditions and reduced consumption of materials.

\subsection{Effect of Temperature}

A number of experimental studies have shown that $\mathrm{Sb}$ removal efficiency, adsorption capacity and adsorption rate can be enhanced at high temperatures $[32,48,50,52,54,67,69]$ whilst keeping other parameters constant. This scenario indicates that the adsorption process is endothermic. The optimal temperature when operational costs are considered should be in the range of $15^{\circ} \mathrm{C}$ to $35^{\circ} \mathrm{C}$ during the adsorption process. However, the removal efficiency of several adsorbents, such as calcite sands loaded with nano $\mathrm{HFO}$ [55], $\mathrm{Fe}_{2} \mathrm{O}_{3}-\mathrm{Fe}_{3} \mathrm{O}_{4} / \mathrm{C}$ prepared with bamboo template [59] and $\mathrm{Fe}_{2} \mathrm{O}_{3}-\mathrm{Fe}_{3} \mathrm{O}_{4} / \mathrm{C}$ prepared with eucalyptus wood template [60], depends weakly on temperature. The adsorption of $\mathrm{Sb}(\mathrm{III})$ onto ferric adsorbents is less affected by temperature change than that of $\mathrm{Sb}(\mathrm{V})$ onto ferric adsorbents. $\mathrm{Sb}$ (III) removal by ferric adsorbents can therefore be applied in low-temperature conditions. The impact degree of temperature on $\mathrm{Sb}$ removal is also related to the physical structure of adsorption materials. For example, the adsorption capacity of $\mathrm{Sb}(\mathrm{V})$ onto $\mathrm{Fe}(\mathrm{III})$ bacteria-treated aerobic granules increases by $6.4 \mathrm{mg} / \mathrm{g}$ when temperature is increased from $10{ }^{\circ} \mathrm{C}$ to $45^{\circ} \mathrm{C}$ [23], whereas the adsorption capacity of $\mathrm{Sb}(\mathrm{V})$ onto $\mathrm{Fe}(\mathrm{III})$-treated aerobic fungal granules shows little change with an increase in temperature [57]. The reason is that an increment in temperature significantly increases the diffusion of $\mathrm{Sb}(\mathrm{V})$ into $\mathrm{Fe}(\mathrm{III})$-treated aerobic bacteria with a dense structure, whereas the effect of $\mathrm{Sb}(\mathrm{V})$ diffusion reaction on $\mathrm{Fe}(\mathrm{III})$-treated fungi aerobic granules is limited because of their rough structure. In conclusion, increasing temperature helps in the removal of $\mathrm{Sb}(\mathrm{V})$ by iron-based adsorption materials, especially for adsorbents with a dense structure. All of these adsorbents can achieve an excellent removal effect in the temperature range of $15^{\circ} \mathrm{C}$ to $35^{\circ} \mathrm{C}$.

\subsection{Effect of Co-Existing/Competing Anions}

The mobility, bioavailability, toxicity and adsorption performance of $\mathrm{Sb}$ in a solution may be considerably affected by coexisting and competing anions, such as nitrate $\left(\mathrm{NO}_{3}{ }^{-}\right)$, chloride $\left(\mathrm{Cl}^{-}\right)$, carbonate $\left(\mathrm{CO}_{3}{ }^{2-}\right)$, sulphate $\left(\mathrm{SO}_{4}{ }^{2-}\right)$, phosphate $\left(\mathrm{PO}_{4}{ }^{3-}\right)$ and silicate $\left(\mathrm{SiO}_{3}{ }^{2-}\right)$. Previous studies $[23,34,47,50,51,54,57,61,62]$ have shown that the adsorption of $\mathrm{Sb}$ on ferric adsorbents is not significantly affected by $\mathrm{Cl}^{-}, \mathrm{NO}_{3}{ }^{-}$or $\mathrm{CO}_{3}{ }^{2-}$. Most experiments $[34,46,51,54,61]$ have demonstrated that the adsorption of $\mathrm{Sb}$ on iron-based adsorbents is unaffected by $\mathrm{SO}_{4}{ }^{2-}$. On the contrary, Zhu [62] found that the existence of $\mathrm{SO}_{4}{ }^{2-}$ promotes the adsorption of $\mathrm{Sb}$ on zero-valent iron. Zhang [55] discovered that $\mathrm{SO}_{4}{ }^{2-}$ hampers the adsorption of $\mathrm{Sb}$ on zero-valence iron. Similar results were obtained by Miao [63]. In addition, $\mathrm{Hu}$ found that $\mathrm{Sb}(\mathrm{V})$ adsorption on $\mathrm{Fe}-\mathrm{Cu}$ binary oxide is more affected by $\mathrm{SO}_{4}{ }^{2-}$ than $\mathrm{Sb}(\mathrm{III})$ adsorption [47]. Consequently, the effects and mechanism of $\mathrm{SO}_{4}{ }^{2-}$ in the adsorption removal of $\mathrm{Sb}$ have raised arguments, and further research is expected. $\mathrm{PO}_{4}{ }^{3-}$ exerts an inhibitory effect on the adsorption of $\mathrm{Sb}(\mathrm{V})$ and $\mathrm{Sb}(\mathrm{III})$ on ferric adsorbents. Phosphate and antimony, with similar molecular structures in compounds, are in the same main group in the periodic table. $\mathrm{PO}_{4}{ }^{3-}$ can thus compete with $\mathrm{Sb}$ for sorption sites on the surface of iron-based adsorbents, and this competition reduces removal efficiency [70]. This finding agrees with the results of studies on arsenite (As) sorption removal from solid residuals by Fe-Mn binary oxide [71]. Through competitive adsorption and electrostatic repulsion, $\mathrm{SiO}_{3}{ }^{2-}$ and $\mathrm{SiO}_{4}{ }^{4-}$ exert significant inhibitory effects when they exist at high concentrations $[38,55,62]$.

Additional cation and anion effects have also been observed. Miao et al. [69] discovered that $\mathrm{Ca}^{2+}$ promotes the adsorption of $\mathrm{Sb}$ on iron-oxide coated calcite sand (IOCCS) and polymeric 
anion exchanger (HFO-201) probably because of the formation of HFO-Ca-Sb complexes [55,57]. Zhu et al. [62] found that the adsorption rate by zero-valent iron is improved by $70 \%$ in a system containing a $\mathrm{Na}^{+}$solution. However, when the $\mathrm{Na}^{+}$concentration in the solution reaches $0.1 \mathrm{~mol} / \mathrm{L}$, the adsorption rate for Fe(III)-treated bacteria granules [23,57], HFO-D201 and IOCCS [55] declines due to the altered anionic form of antimonite. Deng et al. [72] discovered that $\mathrm{Cu}^{2+}$ exerts an inhibitory effect on antimony removal by iron oxide-coated sand and that $\mathrm{Sb}(\mathrm{V})$ and $\mathrm{Sb}(\mathrm{III})$ exhibit low bioavailability in the presence of $\mathrm{Sr}$ or Tc ions in a solution because of co-adsorption reactions [73,74]. By contrast, the presence of $\mathrm{CrO}_{4}{ }^{2-}$ enhances the bioavailability of $\mathrm{Sb}$ in a solution through a competitive adsorption effect that reduces the adsorption of antimony and causes a combined pollution effect. Studies that have reported $\mathrm{As}(\mathrm{III}), \mathrm{Hg}^{2+}$ and $\mathrm{Pb}^{2+}$ as competitive cations on $\mathrm{Sb}$ removal are scarce. The effects of competitive cations, such as $\mathrm{As}(\mathrm{III}), \mathrm{Hg}^{2+}$ and $\mathrm{Pb}^{2+}$, on $\mathrm{Sb}(\mathrm{V})$ and $\mathrm{Sb}(\mathrm{III})$ adsorption removal by iron-based adsorbents remain unclear.

Changes in the ionic strength of solutions also affect $\mathrm{Sb}$ adsorption and desorption. The adsorption of $\mathrm{Sb}(\mathrm{V})$ on iron-modified attapulgite and Fe-Mn binary oxide with increasing ionic strength has been studied $[34,75]$. The capacity to adsorb $\mathrm{Sb}(\mathrm{V})$ on Fe(III)-treated aerobic granules, HFO-201 and IOCCS $[23,55,57]$ decreases with increasing ionic strength, and increasing the ionic strength exerts no significant effect on the adsorption of Sb by iron-zirconium bimetal oxide [46], hematite-modified magnetic nanoparticles [48] and goethite [76]. Several studies have considered the effect of ionic strength on absorption behaviour $[23,34,57,76]$, which influences the nature of the sorption mechanism and the structure of the resultant absorbate. These studies have suggested that, when absorption increases under increasing ionic strength, inner-sphere adsorption occurs on the adsorbent surface. In the reverse process where $\mathrm{Sb}$ is removed or ionic strength decreases, outer-sphere adsorption reactions occur [77]. Spectroscopic evidence is required to confirm this process, and theoretical assumptions need to be substantiated by direct experimental methods, such as extended X-ray absorption fine structure (EXAFS), as evidence for the adsorption mode [77].

Several ionic parameters (e.g., $\mathrm{Sb}(\mathrm{III}), \mathrm{Sb}(\mathrm{V})$, presence of $\mathrm{As}(\mathrm{III}), \mathrm{Hg}^{2+}, \mathrm{SO}_{4}{ }^{2-}$ and $\mathrm{SiO}_{3}{ }^{2-}$ ) influence the field treatment of antimony-contaminated water. The mechanistic details of this influence remain unclear and require further understanding. The inhibition, promotion, competition and synergistic interaction of coexisting/competing ions in $\mathrm{Sb}$ removal require further in-depth research.

\subsection{Effect of Specific Surface Area}

The process of antimony removal from wastewater is controlled by solution solid interface reactions. Consequently, a large specific surface area results in fast reactions and high adsorption capacity of the solid. Guo et al. [45] investigated the adsorption behaviour of Sb with five iron oxides at $\mathrm{pH} 4$. The five forms varied from a crystalline state to an amorphous form. The results showed that surface area and adsorption capacity increased in the descending order of $\mathrm{HFO}>\gamma$-FeOOH $>\beta-\mathrm{FeOOH}$ $>\alpha-\mathrm{FeOOH}>\alpha-\mathrm{Fe}_{2} \mathrm{O}_{3}$. Zhang [63] and Zhao [61] examined the removal efficiency of Sb by nanoscale zero-valent iron and found that the effect of particle size in nanoscale zero-valence iron on the specific surface area of iron salts is superior to that of micron-scale zero-valence iron. A possible explanation is that specific surface area increases with small particle sizes, and the number of adsorption sites for adsorbing heavy metal ions increases. For practical purposes, a small particle size of these adsorbents can increase the difficulty of filtering or prolong the settling time [78]. Therefore, the relationship between specific surface area and particle size needs to be balanced in the development of iron-based adsorption materials to optimise reaction and implementation conditions.

\section{Adsorption Isotherm Models, Adsorption Kinetics and Thermodynamic Models}

\subsection{Adsorption Isotherm Models}

Adsorption isotherms refer to the fraction of adsorbate partitioned between liquid and solid phases at equilibrium. Several sorption models have been studied. For example, Langmuir, Freundlich, 
Temkin, Redlich-Peterson, high-affinity and Dubinin-Radushkevich isotherms have been used to fit the experimental data of adsorption isotherms. The applicability of isotherm models to adsorption study data has been compared by evaluating correlation coefficients or $R^{2}$ values.

Many reports have shown that the Freundlich model has a good fit with experimental data for $\mathrm{Sb}(\mathrm{III})$ and $\mathrm{Sb}(\mathrm{V})$ adsorption on ferric adsorbents, such as Fe-Mn binary oxide [36,37], $\mathrm{FeCl}_{3}$-modifed sepiolite [32], $\mathrm{Fe}_{2} \mathrm{O}_{3}$-modified CNTs [33], iron-modified attapulgite [34], $\mathrm{Fe}(\mathrm{OH})_{3}$ [39], iron-zirconium bimetal oxide [46], hematite-modified magnetic nanoparticles [48] and $\mathrm{FeCl}_{3}$-modifed activated carbon [52]. Adsorption studies on multilayer adsorption focused on physical adsorption combined with simultaneous chemical adsorption. In these cases, all iron-based adsorbents possess similar properties, including high specific surface area, common surface roughness and apparent concave and convex shapes, with high adsorption sites. However, the Langmuir isotherm model describes monolayer adsorption over a homogeneous adsorbent surface by assuming that all adsorption sites have equal solute affinity and that adsorption in one site exerts no impact on adsorption in an adjacent site [56]. The Langmuir isotherm model provides the best fit to $\mathrm{Sb}(\mathrm{V})$ adsorption onto $\mathrm{FeOOH}$ [45], nanoscale zero-valent iron [61], akaganeite [43], Fe(III)-treated aerobic granules [23,57], nano-FeO(OH)-modified clinoptilolite tuff [56] and Fe-Zr-D201 [49]. The surface of these iron-based adsorbents is smooth. $\mathrm{Sb}(\mathrm{III})$ or $\mathrm{Sb}(\mathrm{V})$ adsorption onto $\mathrm{Fe}-\mathrm{Cu}$ binary oxide [47], polymeric anion exchanger D201 loaded with nano HFO [55], calcite sands loaded with nano+ [55] and zeolite-supported magnetite [58] fits Freundlich and Langmuir adsorption models with reasonable success. The results imply that the adsorption process is associated with electrostatic interaction and ion exchange, and the surface of the adsorbents shows similarities in large pore volume but small aperture, as shown by scanning electron microscopy characterisation. Batch equilibrium data on $\mathrm{Sb}$ (III) adsorption onto $\mathrm{Fe}_{3} \mathrm{O}_{4}$ and graphene oxide compound $\left(\mathrm{Fe}_{3} \mathrm{O}_{4} / \mathrm{GO}\right)$ fit Langmuir and Timkin models well, which indicates that the adsorption process is mainly chemical adsorption [54].

The regression coefficients for adsorption isotherms are affected by initial $\mathrm{pH}$. The Langmuir model is the best model for describing the adsorption behaviour of $\mathrm{Sb}(\mathrm{V})$ onto ferrihydrite at $\mathrm{pH} 5$, and when $\mathrm{pH}$ between 7 to 9, and the Freundlich model is the best [68]. The removal of $\mathrm{Sb}(\mathrm{V})$ by ferrihydrite is monolayer adsorption at $\mathrm{pH} 5$ but multilayer adsorption at $\mathrm{pH} 7$ to 9 . When $\mathrm{pH} \leq 6$, $\mathrm{Sb}(\mathrm{V})$ adsorption on $\mathrm{Fe}(\mathrm{OH})_{3}$ fits the high-affinity isotherm well and the Freundlich isotherm at $\mathrm{pH}>6$. These results indicate that $\mathrm{Sb}(\mathrm{V})$ is strongly adsorbed on the $\mathrm{Fe}(\mathrm{OH})_{3}$ surface at $\mathrm{pH}$ below 7 .

Adsorption isotherm models reflect the relationship between adsorption capacity and solution equilibrium concentration when equilibrium is reached at a particular temperature. The definition and precision of fit of these models are related to specific adsorbent species, valency of antimony, initial concentration and $\mathrm{pH}$ and other solution conditions. Determining the interaction between adsorbate and adsorbent through adsorption isotherm models and selecting suitable adsorption materials remain key points for future research to provide practical recommendations for treatment options [79].

\subsection{Adsorption Kinetics}

Adsorption kinetics depends on or is controlled by the physical and chemical characteristics of adsorbents during mass transfer. Studies have been conducted on well-known kinetic models to establish the kinetic characteristics of the adsorption process of $\mathrm{Sb}(\mathrm{III})$ and $\mathrm{Sb}(\mathrm{V})$ ions onto iron-based adsorbents from aqueous solutions. They include pseudo-first-order, pseudo-second-order, fraction power function, Lagergren, intra-particle diffusion, liquid film diffusion, first-order-linear and Elovich kinetic models.

The adsorption of $\mathrm{Sb}(\mathrm{III})$ or $\mathrm{Sb}(\mathrm{V})$ onto most iron-based adsorbents follows the pseudo-second-order kinetic model $[23,32,34,37,38,40,42,50,55,57,58,61]$. The adsorption process is mainly classified as chemisorption, and the power source of adsorption is from the sharing or exchanging of electrons between the adsorbate and adsorbent. Wang et al. [23] reported that the adsorption removal of $\mathrm{Sb}(\mathrm{V})$ by $\mathrm{Fe}(\mathrm{III})$-treated aerobic bacterial granules fits the pseudo-second-order model but cannot explain the two stages in the adsorption process showing fast and slow adsorption 
phases due to the presence of two adsorbate species (Fe(III) and bacteria) in the solution. The results of batch static adsorption using $\mathrm{Fe}_{3} \mathrm{O}_{4} / \mathrm{GO}$ to adsorb $\mathrm{Sb}$ (III)show that kinetic data are best fitted with pseudo-first-order kinetic and intra-particle diffusion models, indicating that membrane diffusion plays a dominant role in the initial stage of the adsorption process [54].

The adsorption kinetics of $\mathrm{Sb}$ (III) onto zero-valence iron [63], $\mathrm{FeCl}_{3}$-modifed activated carbon [33] and $\mathrm{Fe}_{2} \mathrm{O}_{3}$-modified CNTs [52] and of $\mathrm{Sb}(\mathrm{V})$ onto I [69] fit the first-order-linear, Lagergren's first-order and intra-particle diffusion kinetic models well, respectively. Pseudo-first-order and pseudo-second-order kinetic models provide the best description of adsorption of $\mathrm{Sb}$ (III) onto MNP@hematite [48]. The dynamic Elovich model has been utilised to describe the adsorption of $\mathrm{Cd}^{2+}$ and $\mathrm{Sb}(\mathrm{V})$ on Fe-Mn binary oxides in a competing system [66]. The proposed adsorption mechanisms include multi-layer adsorption and heterogeneous diffusion, and significant differences exist between $\mathrm{Cd}^{2+}$ and $\mathrm{Sb}(\mathrm{V})$ in single and competing systems [75]. The Elovich model closely describes the adsorption of $\mathrm{Sb}(\mathrm{V})$ onto ferric soil (red soil) at high $\mathrm{Sb}(\mathrm{V})$ concentrations with a pseudo-second-order kinetic model that functions reliably at low $\mathrm{Sb}(\mathrm{V})$ concentrations [64]. This characteristic reflects the combination of chemical reaction and diffusion processes affecting the adsorption dynamics of $\mathrm{Sb}(\mathrm{V})$ on the soil surface.

The kinetics of adsorption models can be used to define the potential rate control and adsorption mechanism for mass transfer and chemical reaction in the adsorption process. Therefore, a well-defined and studied kinetic adsorption model should be used. Multiple model descriptions can provide successful descriptions and integrate them into the definition of practical treatment processes.

\subsection{Thermodynamic Model of Adsorption}

The nature of thermodynamic conditions during adsorption can provide information on the nature of the surface and adsorbed phase. Thermodynamic adsorption parameters are crucial because they can be used to conclude whether the adsorption is spontaneous or not and can provide information on the nature of adsorption. Three basic thermodynamic parameters, namely, standard Gibbs free energy $\left(\Delta G^{\circ}\right)$, standard enthalpy change $\left(\Delta H^{\circ}\right)$ and standard entropy change $\left(\Delta S^{\circ}\right)$, are frequently defined and utilized to evaluate the effect of temperature on the adsorption of $\mathrm{Sb}$ ions onto iron-based adsorbents. Several studies have suggested that under the conditions of high $\mathrm{Sb}$ concentration, the adsorption of $\mathrm{Sb}$ on most iron-based adsorbents is spontaneous and endothermic [23,34,39,41,42,47,54,57,61,66,67], and low temperatures hinder the reaction. Hydrolysis of antimony increases the randomness in the adsorption system [80]. This finding suggests that chemical and physical adsorption occur [81] during the adsorption process, accompanied by ion exchange $[50,55]$ and oxidation/reduction $[62,82]$. This condition agrees with the use of different adsorption materials for cadmium removal [83-85]. The adsorption of $\mathrm{Sb}(\mathrm{III})$ onto goethite and of $\mathrm{Sb}(\mathrm{V})$ onto amorphous iron oxides have been found to be exothermic. Such adsorption is favoured at low temperatures, in this case, the low concentration of antimony is adsorbed with high activity sites (goethite surface), and the process must be accompanied by strong bond formation and high energy input [86].

\section{Exploring Adsorption Mechanisms}

Many characterisation techniques, such as Fourier transform infrared spectroscopy (FTIR), energy dispersive $\mathrm{X}$-ray spectroscopy, extended $\mathrm{X}$ ray absorption fine structure (EXAFS) and X-ray photoelectron spectroscopy (XPS) have been used to analyse adsorption mechanisms based on the isoelectric point, surface morphology, ionic valence state and near atom bonds, surface functional group and spatial structure.

\subsection{FTIR Analysis}

FTIR provides chemical bond information and can be utilised to distinguish the outer and inner layers of the complexation structure of an adsorption product, and it is an effective tool for studying the behaviour of $\mathrm{Sb}$ during adsorption. The results obtained by FTIR show that sepiolite [32], 
attapulgite [34] and activated carbon [52] modified by iron salts increase the amount of hydroxyl groups on the surface, thereby enhancing the adsorption capability of the material.

Several researchers have found that the Fe-OH band in iron oxide-coated sand [50], iron-modified sepiolite [32], Fe-Mn binary oxide [36] and FeOOH [36] disappears after Sb adsorption with the help of the FTIR technique, which implies participation in the reaction. Miao [55] found that the characteristic absorption peak of the Sb-O band disappears and the characteristic absorption peak of the Fe-O band shifts after the adsorption of $\mathrm{Sb}(\mathrm{V})$ onto HFO-201 and IOCCS. A chemical interaction occurs and forms a new $\mathrm{Sb}-\mathrm{O}-\mathrm{Fe}$ bond, and the preferential adsorption of $\mathrm{Sb}(\mathrm{V})$ onto HFO-related hybrids are mainly attributed to the inner-sphere complexation of $\mathrm{Sb}(\mathrm{V})$ with HFO. A similar result was obtained by Mccomb et al. [87]. FTIR spectra revealed that the shifts in the absorbance of hydroxyl groups in iron oxide were related to the formation of $\mathrm{Fe}-\mathrm{O}-\mathrm{Sb}$ bonds and provided evidence on inner-sphere bond formation [88]. Zhao et al. [61] investigated the adsorption mechanism of antimony onto polyvinyl alcohol (PVA)- $\mathrm{Fe}^{0}$ by using FTIR. Symmetric stretching vibration and bending vibration absorption kurtosis of $\mathrm{Sb}-\mathrm{O}-\mathrm{Sb}$ appeared, which indicated that interactions exist between $\mathrm{Fe}-\mathrm{O}$ and $\mathrm{Sb}(\mathrm{III})$ or $\mathrm{Sb}(\mathrm{V})$. Mittal et al. [67] investigated the adsorption of $\mathrm{Sb}(\mathrm{III})$ oxyanions on a magnetite surface in an aqueous organic acid environment and discovered that tartaric acid exerts the most significant effect on $\mathrm{Sb}$ (III) adsorption on $\mathrm{Fe}_{3} \mathrm{O}_{4}$ amongst the studied organic acids. The reason was that tartaric acid possesses two sets of adjacent functional groups, $\mathrm{O}=\mathrm{C}-\mathrm{OH}$ and $\mathrm{C}-\mathrm{OH}$, which is responsible for the formation of five-membered bidentate chelate with $\mathrm{Sb}(\mathrm{III})$. The FTIR analysis also revealed the complexation of $\mathrm{Sb}(\mathrm{III})$ and magnetite surface hydroxyl was the chief adsorption mechanism. This complexation process is accompanied by the oxidation-reduction reaction of $\mathrm{Sb}$ and Fe. The results from FTIR showed that the surface of clinoptilolite tuff was loaded with ferrihydrite, and, to a lesser extent, $\mathrm{Fe}_{2} \mathrm{O}_{3}$ and hematite after modification by nano- $\mathrm{FeO}(\mathrm{OH})$, and the mechanism of $\mathrm{Sb}(\mathrm{III})$ removal is found to be by ion exchange and surface complexation [56]. The results from FTIR revealed the incorporation of the amino and hydroxyl groups of biomass into the Fe-treated material with sulphur or phosphate groups when aerobic granules were treated with Fe(III) [23].

\subsection{XPS Characterization}

Studies have also been conducted on ferric adsorbent surface phenomena and their surface microtopography by means of the ultra-high vacuum XPS technique. Such a surface analytical and thin-film technique enables the investigation not only of the quantitative elemental composition of solid surfaces, but also of various diffusion, oxidation and other processes and ongoing reactions with iron-based adsorbents. They include the concentration and distribution profiles of host species, microstructural irregularities, surface interfaces and bonding energies [56].

With the help of XPS, Hu et al. [64] found that the chemical states of $\mathrm{Fe}$ and $\mathrm{Cu}$ cations in a $\mathrm{Fe}-\mathrm{Cu}$ binary oxide sample are unchanged in the adsorption process of $\mathrm{Sb}(\mathrm{III})$, which confirm that an oxidation-reduction reaction do not occur. Therefore, they deduced that the removal of $\mathrm{Sb}$ (III) by $\mathrm{Fe}-\mathrm{Cu}$ binary oxide is mainly through adsorption. However, in the adsorption of Sb by goethite [45], iron-modified attapulgite [34], $\mathrm{Fe}_{3} \mathrm{O}_{4} / \mathrm{GO}$ [54] and iron-oxide coated sand (IOCS) [50], oxygen groups tend to donate electrons, whereas iron and antimony tend to accept electrons, and their electron density changes. A redox reaction thus occurs during the adsorption process, which contradicts the conclusion of Hu et al. [64].The results from XPS showed that the Fe-OOH groups within Fe-Mn binary oxide(FMBO)are the main adsorption sites available for $\mathrm{Sb}$, whereas the $\mathrm{Mn}-\mathrm{OOH}$ groups act for the oxidation of $\mathrm{Sb}$ (III) [36], the oxidation and sorption mechanism reasonably explains the $\mathrm{Sb}$ (III) uptake by FMBO. Zhao et al. [61] found that the uptake mechanism for antimony by nanoscale zero-valence iron $\left(\mathrm{Fe}^{0}\right)$ was a chemical reaction. The characterisation obtained by XPS showed that $\mathrm{Fe}^{0}$ is present in an acetalised PVA matrix before adsorption, and it is converted into magnetite $\left(\mathrm{Fe}_{3} \mathrm{O}_{4}\right)$ after $\mathrm{Sb}(\mathrm{III})$ and $\mathrm{Sb}(\mathrm{V})$ adsorption. 


\subsection{XAFS Analysis}

XAFS is a structural analysis method based on synchrotron radiation sources [89]. This method can be used on in situ samples with high sensitivity. Thus, it is considered the most effective means to study the adsorption mechanism of metal-metal systems. With unique advantages in defining the microstructure of adsorbed products and providing an opportunity to model inner-or outer-sphere complexation [90], XAFS is also used to analyse the types of adsorption products. Scheinost et al. [91] deduced from EXAFS spectrometry that the interatomic distances in $\mathrm{Sb}-\mathrm{Fe}$ interactions are in line with an $\mathrm{Sb}(\mathrm{OH})_{6}$ octahedron sharing an edge with an $\mathrm{Fe}(\mathrm{OH})_{6}$ octahedron, thus suggesting the formation of edge-sharing inner-sphere sorption complexes on the goethite surface. The main mechanism of the formation of an inner-sphere complex on the goethite surface is ligand exchange. Qi et al. [92] investigated the mechanism of the interfacial reactions between different iron salts and $\mathrm{Sb}$ ions with the help of XAFS technology. They found that the mechanism is driven by complexation and electrostatic forces and that the competitive adsorption of $\mathrm{Sb}(\mathrm{V})$ and $\mathrm{Sb}(\mathrm{III})$ is driven by the $\mathrm{pH}$ of the reaction solution. Lin [82] and $\mathrm{Zhu}$ [62] found that the removal of $\mathrm{Sb}$ (III) by zero-valence iron under the condition of a weak magnetic field is mainly due to the oxidation of $\mathrm{Sb}(\mathrm{III})$ to $\mathrm{Sb}(\mathrm{V})$ and adsorption and co-precipitation onto the ion oxides formed from the accelerated corrosion of zero-valent iron (ZVI), as evidenced by Sb K-edge EXAFS. Similar observations were obtained in other studies that used XAFS to determine the $\mathrm{Sb}$ species adsorbed on ferrihydrite, manganite and goethite $[45,93]$. These results were similar to those reported for arsenic in which the adsorbed As(III) is partially converted into $\mathrm{As}(\mathrm{V})$ on the surface of ferrihydrite [94].

\subsection{Surface Complexation Model}

Surface complexation model (SCM), which yields a mechanistic understanding of adsorption reactions, has been applied to model metal adsorption onto iron-based adsorbents and other materials [88]. SCM is a tool that relates the adsorption process to equilibrium conditions in the aqueous phase. The model has a thermodynamic basis, which indicates that hypothetical surface species can be used to describe the equilibrium relationship at solid/water interfaces.

Hayes et al. [95] used a generalised version of a triple-layer surface complexation model that considers the formation of outer-and inner-sphere complexes to explore the effects of changes in ionic strength on the adsorption behaviour of selenite and selenate on goethite and hydrous ferric oxide. They postulated that the adsorption capacities of adsorbents, which were relatively unaffected by changes in ionic strength, were best modelled by assuming that an inner-sphere (surface coordination) complex was formed, markedly reduced by increasing ionic strength and best modelled by assuming that an outer-sphere (ion pair) surface complex was formed. The results also suggested that innerand outer-sphere anion surface complexes could be distinguished by studying the effect of ionic strength on anion partitioning. On this basis, $\mathrm{Xu}$ et al. [37] found that $\mathrm{Sb}(\mathrm{V})$ removal was promoted under high-ion-strength conditions and deduced that $\mathrm{Sb}(\mathrm{V})$ removal was achieved by the formation of inner-sphere surface complexes at the water/oxide interface on FMBO. For Sb, surface complexation reactions, as suggested by Guo et al. [45], provide the best fit for experimental results, and the surface complexation reactions are similar for two Sb species, namely, $\mathrm{Sb}(\mathrm{III})$, which is adsorbed as an inner-sphere $>\mathrm{FeOSb}(\mathrm{OH})_{2}$ complex, and $\mathrm{Sb}(\mathrm{V})$, which is adsorbed as an inner-sphere $>\mathrm{FeOSb}(\mathrm{OH})_{5}{ }^{-}$ complex. Deng et al. [72] proposed the mechanism of Sb adsorption on IOCS according to the triple-layer model [96]. The mechanism is that a bidentate surface complex and a monodentate surface complex are formed by the two-stage reaction between $\mathrm{Sb}(\mathrm{OH})_{3}$ and surface hydroxyl groups of IOCS and the reaction between $\mathrm{HSbO}_{2}$ and surface hydroxyl groups of IOCS, respectively. Paul et al. [97] proposed a similar adsorption mechanism of $\mathrm{H}_{2} \mathrm{AsO}_{4}{ }^{-}$adsorption/desorption onto goethite $(\alpha-\mathrm{FeOOH})$ by using a pressure-jump relaxation technique. The results indicated that arsenate forms an inner-sphere bidentate surface complex with goethite. The mechanism of $\mathrm{Sb}(\mathrm{V})$ onto $\mathrm{Fe}(\mathrm{III})$-treated aerobic granules was inferred based on experimental results and a relevant surface complexation model. The surface of Fe(III)-treated aerobic granules was positively charged due to 
protonation at $\mathrm{pH}$ 3.4. $\mathrm{Sb}(\mathrm{V})$ in the form of $\mathrm{Sb}(\mathrm{OH})_{6}{ }^{-}$then went near the micro-interface of $\mathrm{Fe}(\mathrm{OH})_{3}$ by an electrostatic interaction. Subsequently, an outer-sphere complex was established through ion exchange, and an inner-sphere complex could be formed further [23,57].

Guo et al. [98] deduced from the diffuse-layer model that, similar to arsenic, antimony is likely adsorbed onto HFO and other iron oxyhydroxides by an inner-sphere complex. $\mathrm{Sb}$ (III)/HFO complexation exhibits intrinsic surface complexation constants more than two orders of magnitude greater than those of $\mathrm{Sb}(\mathrm{V}) / \mathrm{HFO}$ complexation. The effects of phosphate and humic acid on $\mathrm{Sb}$ (III) removal are greatly reduced by the strong affinity between $\mathrm{Sb}$ (III) and HFO.

\section{Conclusions}

$\mathrm{Sb}$ and its compounds are considered global, priority pollutants. The existence of elevated levels of $\mathrm{Sb}$ in water environments has been of particular interest to the scientific community. Iron-based adsorbents are commonly viewed as useful materials for removing trace contaminants from water. From the perspective of the practical application of iron-based adsorbents to treat major $\mathrm{Sb}$ pollution problems, the following aspects should be emphasised:

- Iron-based adsorbents are functionally superior to many common aqueous metal sorption systems. $\mathrm{pH}$, contact time, initial concentration, adsorbent dose, temperature, specific surface area and co-existing/competing ions are the factors to affect the adsorption of Iron-based adsorbents. In addition, $\mathrm{pH}$ is the most crucial factor and must remain a high priority during adsorption process.

- New iron-based absorbents with simple, environment-friendly and low-cost procedures should be explored. The binary metal oxides, such as iron-zirconium and iron-manganese yielded very interesting results, considering their considerable adsorption capacities and low cost.

- Many in depth and comprehensive research studies including adsorption isotherm, kinetics and thermodynamic have been published. The Freundlich model has a good fit with experimental data for $\mathrm{Sb}(\mathrm{III})$ and $\mathrm{Sb}(\mathrm{V})$ adsorption on many Iron-based adsorbents, which indicates that the adsorption process is mainly chemical adsorption. The adsorption of $\mathrm{Sb}(\mathrm{III})$ or $\mathrm{Sb}(\mathrm{V})$ onto most iron-based adsorbents follows the pseudo-second-order kinetic model.

- The removal mechanisms and possibility of redox reactions and conversion between $\mathrm{Sb}(\mathrm{III})$ and $\mathrm{Sb}(\mathrm{V})$ during the adsorption process should be considered comprehensively. Quantitative-qualitative analysis of the mechanisms of complexing, electrostatic attraction, redox and ion exchange can be improved through modern analytical technologies, such as FTIR, XPS, atomic force microscopy and X-ray absorption near-edge structure. Such an analysis is a priority to optimise the regulation of adsorption sites and functional groups and to enhance adsorbent performance. Doing so would provide theoretical and technical support for the efficient adsorption treatment of Sb-contaminated wastewater.

Acknowledgments: This study was financially supported by the National Natural Science Foundation of China (No. 41672350) and the National Natural Science Foundation of China Hunan Province (No. 2016JJ6041). Andrew S. Hursthouse acknowledges the support of Hunan Provincial Government and Hunan University of Science \& Technology through the High End Expert Scholarship.

Author Contributions: R.-J.D. and C.-S.J. conceived and designed the study. B.-Z.R. and B.-L.H. analyzed the data. R.-J.D. and C.-S.J. wrote the paper. A.S.H. assessed data, reviewed and edited the manuscript. All authors read and approved the manuscript.

Conflicts of Interest: The authors declare no conflict of interest.

\section{References}

1. Johnson, C.A.; Moench, H.; Wersin, P.; Kugler, P.; Wenger, C. Solubility of antimony and other elements in samples taken from shooting ranges. Environ. Qual. 2005, 34, 248-254. 
2. He, M.C.; Wan, H.Y. Distribution, speciation, toxicity and bioavailability of antimony in the environment. Prog. Chem. 2004, 16, 131-135.

3. Ning, Z.P.; Xiao, T.F. Supergene geochemical behavior and environmental risk of antimony. Earth Environ. 2004, 35, 176-182.

4. Wu, F.C.; Zheng, J.; Pan, X.L.; Li, W.; Deng, Q.; Mo, C.; Zhu, J.; Liu, B.; Shao, S.; Guo, J. Prospect on Biogeochemical cycle and Environmental effect of antimony. Adv. Earth Sci. 2008, 23, 350-356.

5. He, M.C.; Wang, X.Q.; Wu, F.C.; Fu, Z. Antimony pollution in China. Sci. Total Environ. 2012, 421, 41-50. [CrossRef] [PubMed]

6. Indika, H.; Meththika, V.; Jochen, B. Antimony as a global dilemma: Geochemistry, mobility, fate and transport. Environ. Pollut. 2017, 223, 545-559.

7. Li, Z.B. Water Quality Analysis and Treatment Technology Research of Acid Mine Drainage from Banpo Antimony Mine in Guizhou Province. Master's Thesis, Guizhou Normal University, Guiyang, China, 2014; pp. 1-72.

8. Zhu, J.; Wu, F.C.; Deng, Q.J.; Shao, S.X.; Mo, C.L.; Pan, X.L.; Li, W.; Zhang, R.Y. Environmental characteristics of water near the Xikuangshan antimony mine, Hunan Province. Acta Sci. Circumstantiae 2009, 29, 655-661.

9. Li, M.S.; Li, J.; Wang, G.J. Research advances in microbial of antimony. J. Huazhong Agric. Univ. 2013, 45, $15-19$.

10. Antimony Threatens Drinking Water Safety in Guangxi Province. Available online: http:/ / www.most.gov. cn/kjbgz/201202/t20120221_92589.htm (accessed on 22 February 2012).

11. Du, X.; Liang, H.; Qu, F.S.; Huang, Y.; Ye, T.; Li, G. An approach for thallium and antimony combined pollution removal in drinking water using potassium permanganate composites and polymeric ferric sulfate. J. Harbin Inst. Technol. 2013, 45, 33-37.

12. Amarasiriwardena, D.; Fengchang, W. Antimony: Emerging toxic contaminant in the environment. Microchem. J. 2008, 97, 1-3. [CrossRef]

13. Chen, Q.P.; Xu, S.Q.; Sun, H.R.; Chen, Q.; Xu, S.; Sun, H.; Ren, H.; Xu, S.L.; Zhang, Y.X. Speciation distribution and ecological risk assessment of antimony and arsenic in soils of the antimony mining area. Earth Environ. 2014, 43, 773-778.

14. He, M.C.; Yun, Y. The speciation and bioavailability of antimony in the soils near antimony mine area. Environ. Chem. 2003, 14, 126-130.

15. Wang, X.L.; Wei, Z.Y.; Feng, R.W.; Tu, S.X. The accumulation and transformation of antimony characteristics in Pteris cretica and Brassica Juncea. Acta Sci. Circumstantiae 2014, 12, 720-727.

16. Kyle, J.H.; Breuer, P.L.; Bunney, K.G.; Pleysier, R.; May, P.M. Review of trace toxic elements (Pb, Cd, Hg, $\mathrm{As}, \mathrm{Sb}, \mathrm{Bi}, \mathrm{Se}, \mathrm{Te}$ ) and their deportment in gold processing Part II: Deportment in gold ore processing by cyanidation. Hydrometallurgy 2012, 111, 10-21. [CrossRef]

17. Zhang, D.Y.; Pan, X.L.; Mu, G.J. Antimony pollution in water and soil and its ecotoxicological effects on plants and microorganisms. Chin. J. Appl. Environ. Biol. 2010, 23, 891-894.

18. Zhang, Y.P.; Zhang, T.; Chen, J.F.; Peng, R. Research progress on present situation and countermeasure of antimony pollution in water and soil environment. Ecol. Environ. Sci. 2011, 20, 1373-1378.

19. Zhang, Y.; Han, Z.Y.; Pang, Z.H.; Peicong, W.Z.L. Emergency disposal of antimony ores wastewater pollution. Ind. Saf. Environ. Prot. 2013, 39, 16-18.

20. Zhang, J.X.; Yang, B.; Wang, C.; Zhao, X. Removal of antimony contaminant in water by electrocoagulation. Chem. J. Environ. Eng. 2014, 8, 4244-4248.

21. Zhang, Z.; Zhao, Y.B.; Liu, R.Y. An experimental study on using micro-electrolysis-neutralization sedimentation process to treat the acidic mine underground. Nonferr. Met. 2002, 2, 45-47.

22. Wang, J.L.; Chen, C. Research advances in heavy metal removal by biosorption. Acta Sci. Circumstantia 2010, 30, 673-701.

23. Wang, L.; Wan, C.L.; Lee, D.J.; Liu, X.; Zhang, Y.; Chen, X.F.; Tay, J.H. Biosorption of antimony(V) onto Fe(III)-treated aerobic granules. Bioresour. Technol. 2014, 158, 351-354. [CrossRef] [PubMed]

24. Wu, S. Behaviours of Biosorption and Desorption of Antimony by Naturally Occurring Cyanobacteria Microcystis. Master's Thesis, Chinese Research Academy of Environmental Sciences, Beijing, China, 2012.

25. Sun, F.H.; Wu, F.C.; Liao, H.Q.; Xing, B. Biosorption of antimony(V) by freshwater cyanobacteria Microcystis biomass: Chemical modification and biosorption mechanisms. Chem. Eng. J. 2011, 171, 1082-1090. [CrossRef] 
26. He, W.N.; Zhao, W.S. Study on the purification of antimony and bismuth in copper electrolyte by exchange adsorption. Nonferr. Met. 1998, 3, 26-28.

27. Ozdemir, N.; Soylak, M.; Elci, L.; Dogan, M. Speciation analysis of inorganic $\mathrm{Sb}(\mathrm{III})$ and $\mathrm{Sb}(\mathrm{V})$ ions by using mini column filled with Amberlite XAD-8 resin. Anal. Chim. Acta 2004, 505, 37-41. [CrossRef]

28. Zhu, J.; Wu, F.C.; Pan, X.L.; Guo, J.; Wen, D. Removal of antimony from antimony mine flotation wastewater by electrocoagulation with aluminum electrodrs. J. Environ. Sci. China 2011, 23, 1066-1071. [CrossRef]

29. Komesli, O.T. Removal of heavy metals in wastewater by membrane bioreactor: Effects of flux and suction period. J. Chem. Soc. Pak. 2014, 36, 654-659.

30. Kamberović, Ž.; Korać, M.; Anđić, Z.; Štulović, M.; Kovačević, T.; Vujović, A.; Ilić, I. Conceptual design for treatment of mining and metallurgical wastewaters which contains arsenic and antimony. Metall. Mater. Eng. 2012, 18, 321-331.

31. Kalderis, D.; Tsolaki, E.; Antoniou, C.; Diamadopoulos, E. Characterization and treatment of wastewater produced during the hydro-metallurgical extraction of germanium from fly ash. Desalination 2008, 230, 162-174. [CrossRef]

32. Li, S.S. The Adsorption Study of Antimony on Iron Modified Sepiolite. Master's Thesis, Xiangtan University, Xiangtan, China, 2009; pp. 1-50.

33. Zeng, C. Removal of Antimony(III) by Adsorption of Modified Carbon Nanotubes. Master's Thesis, Zhejiang University, Hangzhou, China, 2013; pp. 1-72.

34. Zhang, H. Removal of Antimony(V) by Adsorption of Iron-Modified Attapulgite Adsorbent. Master's Thesis, Guizhou University, Guiyang, China, 2015; pp. 1-53.

35. Ungureanu, G.; Santos, S.; Boaventura, R.; Botelho, C. Arsenic and antimony in water and wastewater: Overview of removal techniques with special reference to latest advances in adsorption. J. Environ. Manag. 2015, 151, 326-342. [CrossRef] [PubMed]

36. Xu, W.; Wang, H.; Liu, R.; Zhao, X.; Qu, J. The mechanism of antimony(III) removal and its reactions on the surfaces of Fe-Mn binary oxide. J. Colloid Interface Sci. 2011, 363, 320-326. [CrossRef] [PubMed]

37. Xu, W.; Liu, R.P.; Qu, J.H.; Peng, R.M. The adsorption behavioursof Fe-Mn binary oxide towards $\mathrm{Sb}(\mathrm{V})$. Acta Sci. Circumstantiae 2012, 32, 270-275.

38. Li, X.H.; Dou, X.M.; Li, J.Q. Antimony(V) removal from water by iron-zirconium bimetal oxide: Performance and mechanism. J. Environ. Sci. 2012, 24, 1197-1203. [CrossRef]

39. Han, L.; Lu, S.S.; Gu, S.Y. Study of absorption of $\mathrm{Sb}(\mathrm{V})$ onto $\mathrm{Fe}(\mathrm{OH}) 3$. J. Guizhou Univ. Nat. Sci. 2013, 30, 132-135.

40. Xi, J.H.; He, M.C.; Wang, H.P.; Zhang, G. Adsorption of antimony(III) on goethite in the presence of competitive anions. J. Geochem. Explor. 2013, 132, 201-208. [CrossRef]

41. Watkins, R.; Weiss, D.; Dubbin, W.; Peel, K.; Coles, B.; Arnold, T. Investigations into the kinetics and thermodynamics of $\mathrm{Sb}(\mathrm{III})$ adsorption on goethite (alpha-FeOOH). J. Colloid Interface Sci. 2006, 303, 639-646. [CrossRef] [PubMed]

42. Wang, H.W.; Li, X.Y.; Li, W.H.; Sun, Y.L. Effects of $\mathrm{pH}$ and complexingagents on $\mathrm{Sb}(\mathrm{V})$ adsorption onto binessite and ferrihydrite surface. Environ. Sci. 2017, 38, 180-187.

43. Kolbe, F.; Weiss, H.; Morgenstern, P.; Wennrich, R.; Lorenz, W.; Schurk, K.; Stanjek, H.; Daus, B. Sorption of aqueous antimony and arsenic species akaganeite. J. Colloid Interface Sci. 2011, 357, 460-465. [CrossRef] [PubMed]

44. Ambe, S. Adsorption-kinetics of antimony(V) ions onto alpha- $\mathrm{Fe}_{2} \mathrm{O}_{3}$ surfaces from an aqueous-solution. Langmuir 1987, 3, 489-493. [CrossRef]

45. Guo, X.J.; Wu, Z.J.; He, M.C.; Meng, X.; Jin, X.; Qiu, N.; Zhang, J. Adsorption of antimony onto iron oxyhydroxides: Adsorption behavior and surface. J. Hazard. Mater. 2014, 276, 339-345. [CrossRef] [PubMed]

46. Cheng, K.; Chen, L. Investigation of deeply removal of antimony(V) from water by Fe-Zr binary metal oxides. Environ. Sci. Technol. 2015, 28, 21-23.

47. Hu, X.X. Study on the Performance and Mechanism of the Removal of Antimony from Mine Wastewater by a New Type of Fe-Cu Binary Oxide. Master's Thesis, Hunan University of Science and Technology, Xiangtan, China, 2016; pp. 1-73.

48. Shan, C.; Ma, Z.; Tong, M. Efficient removal of trace antimony(III) through adsorption by hematite modified magnetic nanoparticles. J. Hazard. Mater. 2014, 268, 229-236. [CrossRef] [PubMed] 
49. Liu, X.W.; Chen, J.H.; Chen, J.Q. Removal of antimony from water by supported iron-zircon bimetal oxide polymeric anion exchange resin. Ion Exch. Adsorpt. 2016, 32, 244-252.

50. Xu, G.M.; Shi, Z.; Deng, J. Removal of antimony from water by iron-oxide coated sand. Environ. Sci. 2006, 25, 481-484.

51. Kumar, B.B.; Moue, J.; Kawakita, H.; Ohto, K.; Inoue, K. Effective removal and recovery of antimony using metal-loaded saponified orange waste. J. Hazard. Mater. 2009, 172, 721-728.

52. Wang, X.H. Study on Removal of $\mathrm{Sb}(\mathrm{III})$ in Aqueous Solution by $\mathrm{FeCl}_{3}$-Modified Activated Carbon. Master's Thesis, Zhejiang University, Hangzhou, China, 2012; pp. 1-70.

53. Bhakhar, N. Antimony Removal by Iron-Oxide Coated Olivine and Water Treatment Residual. Master's Thesis, Royal Institute of Technology-KTH, Stockholm, Sweden, 2006.

54. Yang, X.Z. Study on Adsorption of Antimony(III) from Aqueous Solution Using Graphene Oxide and It's Magnetite Composites. Master's Thesis, Hunan University, Changsha, China, 2015; pp. 1-115.

55. Miao, Y.Y. Removal of Aqueous $\mathrm{Sb}(\mathrm{V})$ by Adsorbents Loaded with Nano Hydrated Ferric Oxides. Master's Thesis, Nanjing University, Nanjing, China, 2013; pp. 1-51.

56. Chmielewská, E.; Tylus, W.; Drabik, M.; Majzlan, J.; Kravčak, J.; Williams, C.; Čaplovičová, M.; Čaplovič, L. Structure investigation of nano- $\mathrm{FeO}(\mathrm{OH})$ modified clinoptilolite tuff for antimony removal. Microporous Mesoporous Mater. 2017, 248, 222-233. [CrossRef]

57. Wan, C.; Wang, L.; Lee, D.; Zhang, Q.; Li, J.; Liu, X. Fungi aerobic granules and use of Fe(III)-treated granules for biosorption of antimony(V). J. Taiwan Inst. Chem. Eng. 2014, 45, 2610-2614. [CrossRef]

58. Verbinnen, B.; Block, C.; Lievens, P.; Van Brecht, A.; Vandecasteele, C. Simultaneous removal of molybdenum, antimony and selenium oxyanions from wastewater by adsorption on supported magnetite. Waste Biomass Valorization 2013, 4, 635-645. [CrossRef]

59. Zhu, Z.Q.; Mo, C.; Wei, W.H.; Zhu, Y.; Huang, X.; Huang, B. Absorption of Sb(III) from aqueous solution by the porous biomorph-genetic composition of $\mathrm{Fe}_{2} \mathrm{O}_{3} / \mathrm{Fe}_{3} \mathrm{O}_{4} / \mathrm{C}$ prepared with bamboo template. Ind. Saf. Environ. Prot. 2016, 42, 51-53.

60. Wei, W.H.; Zhu, Z.Q.; Zhu, Y.N.; Hui, Q.; Meina, L. Adsorption of Sb(III) from aqueous solution by the porous biomorph-genetic composite of $\mathrm{Fe}_{2} \mathrm{O}_{3}-\mathrm{Fe}_{3} \mathrm{O}_{4} / \mathrm{C}$ prepared with eucalyptus wood template. Technol. Water Treat. 2013, 39, 69-72.

61. Zhao, X.Q. Antimony Removal from Water by Fe and Al-Based Adsorbents Performance and Mechanism. Master's Thesis, Beijing Forestry University, Beijing, China, 2014; pp. 1-71.

62. Zhu, L.J. Mechanisms of Removing Chromium or Antimonite Using Zero-Valent Iron. Master's Thesis, Shandong University, Jinan, China, 2015; pp. 1-63.

63. Zhang, D.Y.; Pan, X.L.; Song, Y.X. Removal of antimony from water by zero-valent iron. Earth Environ. 2009, 37, 315-318.

64. Li, L.L.; Xu, S.H.; Zhang, H.; Zhou, S.W. Pentavalent antimony adsorption behaviours in two types of soils typical to south China. Acta Pedol. Sin. 2014, 51, 278-285.

65. Filella, M.; Belzile, N.; Chen, Y.W. Antimony in the environment: A review focused on natural waters II. Relevant solution chemistry. Earth-Sci. Rev. 2002, 59, 265-285. [CrossRef]

66. Liu, F.; Liu, R.P.; Liu, H.J.; Qu, J.H. The adsorptive behaviours of Fe-Mn binary oxides towards antimony and cadmium. Acta Sci. Circumstantiae 2013, 33, 3189-3196.

67. Mittal, V.K.; Bera, S.; Narasimhan, S.V.; Velmurugan, S. Adsorption behaviour of antimony(III) oxyanions on magnetite surface in aqueous acid environment. Appl. Surf. Sci. 2013, 266, 272-279. [CrossRef]

68. Xie, Z.M.; Chen, Z.; Liu, T.G.; Dai, Y.Z. Study on the influential factors on the removal of antimony by ion modified sepiolite and its regeneration conditions. Ind. Water Treat. 2009, 29, 35-38.

69. Miao, Y.; Han, F.; Pan, B.; Niu, Y.; Nie, G.; Lv, L. Antimony(V) removal from water by hydrated ferric oxides supported by calcite sand and polymeric anion exchanger. J. Environ. Sci. 2014, 26, 307-314. [CrossRef]

70. Ghosh, A.; Saez, A.E.; Ela, W. Effect of $\mathrm{pH}$, competitive anions and NOM on the leaching of arsenic from solid residuals. Sci. Total Environ. 2006, 363, 46-59. [CrossRef] [PubMed]

71. Zhang, G.; Qu, J.; Liu, H.; Liu, R.; Wu, R. Preparation and evaluation of a novel Fe-Mn binary oxide adsorbent for effective arsenite removal. Water Res. 2007, 41, 1921-1928. [CrossRef] [PubMed]

72. Deng, J.; Shi, Z.; Xu, G.M. Adsorption of antimony on IOCS: Kinetics and mechanisms. Ind. Water Wastewater 2009, 40, 19-23. 
73. Zhang, L.; Wei, J.Y.; Zhao, X.; Li, F.Z.; Jiang, F. Preparation, characterization and Sr(II) adsorption performance of self-doped antimony oxide. Acta Phys.-Chim. Sin. 2014, 30, 1923-1931.

74. Xia, D.Y.; Zeng, D.Y. Studies of sorption of radioactive technetium on antimony-containing minerals. J. Nucl. Radiochem. 1993, 15, 99-103.

75. Xu, W. Arsenic Desorption and Antimony Adsorption Behaviours on FMBO Surface. Ph.D. Thesis, Chinese Academy of Sciences, Beijing, China, May 2011.

76. Xi, J.H.; He, M.C.; Lin, C.Y.; Zhang, P.; Hu, L.J. Adsorption of antimony(III) on montmorillonite, kaolinite and goethite: Effect of $\mathrm{pH}$ and ionic strength. Environ. Sci. 2009, 28, 54-57.

77. Arai, Y.; Sparks, D.L.; Davis, J.A. Arsenate adsorption mechanisms at the allophane-water interface. Environ. Sci. Technol. 2005, 39, 2537-2544. [CrossRef] [PubMed]

78. Wu, X.; Weng, Y.; Xiao, Y.B.; Qian, S.H. Pre-concentration of trace $\mathrm{Sb}$ in water with nanometer-size $\mathrm{TiO}_{2}$ and its determination by GFAAS. J. Anal. Sci. 2004, 20, 376-378.

79. Wang, L.; Xing, R.; Liu, S.; Qin, Y.; Li, K.; Yu, H.; Li, R.; Li, P. Studies on adsorption behavior of Pb(II) onto a thiourea-modified chitosan resin with $\mathrm{Pb}$ (II) as template. Carbohydr. Polym. 2010, 81, 305-310. [CrossRef]

80. Ayben, K.; Bilgin, B. Thermodynamic and kinetic investigation of uranium adsorption on amberlite IR- $118 \mathrm{H}$ resin. Appl. Radiat. Isot. 2003, 58, 155-160.

81. Tang, H.X.; Qian, Y.; Wen, X.H. The Characteristics and Controling Technical Principle of Water Particles and Refractory Organics in Water (Volume 1): Water Particles; China Environmental Science Press: Beijing, China, 2000.

82. Lin, S. Research on the Mechanism of Sequestration of Antimonite in Aqueous Solution by Zerovalent Iron Under Weak Magnetic Field. Master's Thesis, Shangdong University, Jinan, China, 2016; pp. 1-48.

83. Wang, X.S.; Li, Z.Z.; Tao, S.R. Removal of chromium(VI) from aqueous solution using walnut hull. J. Environ. Manag. 2008, 90, 721-729. [CrossRef] [PubMed]

84. Xu, C.X.; Dai, Y.Z.; Wu, A.M. Biosorption study of $\mathrm{Cr}(\mathrm{VI})$ from aqueous solutions by rice bran and wheat bran. Technol. Water Treat. 2007, 33, 53-56.

85. Ayla, O.; Dursun, O. Comparative study of the biosorption of $\mathrm{Pb}(\mathrm{II}), \mathrm{Ni}(\mathrm{II})$ and $\mathrm{Cr}(\mathrm{VI})$ ions onto S. cerevisiae: Determination of biosorption heats. J. Hazard. Mater. B 2003, 100, 219-229.

86. Yuan, Y.C.; Chen, B.N.; Wang, R.X. Study on preparation and properties of chitosan resin crosslinked by formaldehyde and epichlorohydrin. Polym. Mater. Sci. Eng. 2004, 20, 53-58.

87. Mccomb, K.A.; Craw, D.; Mcquillan, A.J. ATR-IR spectroscopic study of antimonate adsorption to iron oxide. Langmuir 2007, 23, 12125-12130. [CrossRef] [PubMed]

88. Meththika, V.; Anushka, U.R.; Dou, X.M.; Bolan, N.S.; Yang, J.E.; Ok, Y.S. Surfacecomplexationmodelling and spectroscopic evidence of antimony adsorption on iron-oxide-rich red earth soils. J. Colloid Interface Sci. 2013, $406,217-224$.

89. Gaur, A.; Shrivastava, B.D. Speciation using X-ray adsorption fine structure (XAFS). Rev. J. Chem. 2015, 5, 361-398. [CrossRef]

90. O’Day, P.A.; Rehr, J.J.; Zabinsky, S.I.; Brown, G.J. Extended X-ray absorption fine structure (EXAFS) analysis of disorder and multiple-scattering in complex crystalline solids. J. Am. Chem. Soc. 1994, 116, 2938-2949. [CrossRef]

91. Scheinost, A.C.; Rossberg, A.; Vantelon, D.; Xifra, I.; Kretzschmar, R.; Leuz, A.-K.; Funke, H.; AnnetteJohnson, C. Quantitative antimony speciation in shooting-range soils by EXAFS spectroscopy. Geochim. Cosmochim. Acta 2006, 70, 3299-3312. [CrossRef]

92. Qi, P.F.; Pichler, T. Sequential and simultaneous adsorption of $\mathrm{Sb}(\mathrm{III})$ and $\mathrm{Sb}(\mathrm{V})$ on ferrihydrite: Implications for oxidation and competition. Chemosphere 2016, 145, 55-60. [CrossRef] [PubMed]

93. Wang, X.Q.; He, M.C.; Lin, C.Y. Antimony(III) oxidation and antimony(V) adsorption reactions on synthetic manganite. Chem. Erde-Geochem. 2012, 72, 41-47. [CrossRef]

94. Zhao, Z.X.; Jia, Y.F.; Xu, L.Y.; Zhao, S. Adsorption and heterogeneous oxidation of As(III) on ferrihydrite. Water Res. 2011, 45, 6496-6504. [CrossRef] [PubMed]

95. Hayes, K.F.; Papelis, C.; Leckie, J.O. Modelling ionic strength effects on anion adsorption at hydrous oxide/solution interfaces. J. Colloid Interface Sci. 1988, 125, 717-726. [CrossRef]

96. Khemarath, O. Multi-Metal Equilibrium Sorption and Transport Modelling for Copper, Chromium, and Arsenic in An Iron Oxide-Coated Sand, Synthetic Groundwater System. Master's Thesis, The University of Oregon State, Corvallis, OH, USA, 2002. 
97. Paul, R.G.; Matthew, E.; Donald, L.S.; Goldberg, S.; Ainsworth, C.C. Arsenate and chromate retention mechanisms on goethite 2 kinetic evaluation using a pressure-jump relaxation technique. Environ. Sci. Technol. 1997, 31, 321-326.

98. Guo, X.J.; Wu, Z.J.; He, M.C. Removal of antimony(V) and antimony(III) from drinking water by coagulation-flocculation-sedimentation (CFS). Water Res. 2009, 43, 4327-4335. [CrossRef] [PubMed] 